УДК 94

DOI 10.25205/978-5-4437-1268-0-59-66

Stephanie Ziehaus

Palacký University, Olomouc, Czech Republic

\title{
THE QING IN GLOBAL HISTORY AND EMPIRE STUDIES: NEW APPROACHES AND FRONTIERS
}

This paper aims at situating the Qing Empire in the field of Empire-Studies and to determine the place of the Qing in global history. In an effort to shift the focus from the center to the edges of the Empire, New Imperial History has reframed "Empire" as an analytical category, in order to offer a more nuanced perception of empires and include early-modern empires in studies of colonialism and imperialism. Especially with the rise of new paradigms in Empire Studies and the resurgence of national narratives in Chinese historiography, the discussion of approaches on how to integrate the Qing into a global history of Empires represents a timely and urgent addition to New Imperial History and Global History. Through a cross-fertilization of methodologies and approaches - local-historic approach and comparative analysis - Qing history is being placed within broader structures of Empire-Building and interactions between center and periphery. By analyzing the current patterns of Qing Empire Studies, such as the New Qing History and New Qing History Project, this paper is going to showcase points of connections for further future studies on the Qing, in a more globally and less nationally perceived framework.

Key words: Global History; Empire Studies; Qing Empire; Comparative Analysis

\section{Штефани Цихаус}

Университет Палацкого, Оломоуи, Чехия

\section{ЦИН В МИРОВОЙ ИСТОРИИ И В ИЗУЧЕНИИ ИМПЕРИЙ: НОВЫЕ ПОДХОДЫ И ВОЗМОЖНОСТИ}

Данная работа ставит своей целью поместить империю Цин в контекст изучения мировых империи, а также определить ее место в мировой истории. Переосмысление самого понятия Империи как аналитической категории позволяет сместить фокус внимания с центра на ее окраины, перейти к более детальному ее изучению и в результате включить империи раннего Нового времени в исследования колониализма и империализма. С появлением новых исследовательских парадигм и возобновлением национальных нарративов в китайской историографии поиск возможных подходов к вопросу интеграции Цин в историю мировых империй представляет собой своевременную и неотложную исследовательскую задачу в рамках изучения империй и мировой истории. Благодаря взаимодополнению методологий и подходов (локально-исторического подхоа и сравнительного анализа) история Цин рассматривается в более широком контексте по-

(C) S. Ziehaus, 2021 
строения империи и взаимодействия между центром и периферией. Проанализировав в данной статье текущие направления исследований империи Цин, таких как проект «Новая история Цин» и «Проект новой истории Цин», мы продемонстрируем возможные точки соприкосновения разных подходов для дальнейших исследований Цин в более глобальном и менее национально обусловленном контексте.

Ключевые слова: Мировая история, изучение империй, империя Цин, сравнительный анализ.

\section{Introduction}

In recent years, the history of the Qing Empire has received increasing attention. In 2002, the National Project for the Compilation of Qing History (国家清史纂修工程) was officially launched in the People's Republic of China, while some years prior, on the other side of the globe the research field of New Qing History was established by American and British scholars [Crossley, 1999. Elliott, 2006. Hostetler, 2001. Rawski, 1996]. At the same time, in the field of Empire studies, the New Imperial Turn has led to re-evaluation of how empire-building, imperial structures, networks and agents are to be analyzed and introduced new interested in the Empire as an critical analytical category. In tandem with the re-conceptualization of what Empire Studies aim to be and do, there have been valiant efforts to include Empires not traditionally studied, such as the Qing Empire, into the fields of Empire Studies and, even, Global History.

In this paper, I seek to confront research approaches that aim at integrating the Qing Empire into the fabric of Empire Studies as well as into the field comprised under the term "Global History". The most common approach taken refers to the comparative analysis of the Qing with other Empires, mostly the group of "Eurasian Empires" - land-based, multiethnic empires following empire-building strategy of "old imperialism", such as the Russian Empire. This tactic has not only been pursued by the New Qing History scholars, but also - and not less importantly - by Russian scholars that seek to revitalize the study of the Russian Empire.

On the other hand, the research trend encapsulated in the paradigm shift of "New Imperial History" aims to redefine "Empire" as an analytical category, by expanding it to include more Non-European, early modern empires as well as by reconsidering patterns and processes that make up Empire-Building in connection to Post-Colonial Studies. I propose to combine the more traditional approach, connected to the "Eurasian shift", with the call for a more connected, global history of Empires proposed by the "New Imperial History", in order to successfully incorporate the Qing Empire into comparative works of Empire Studies and Global History alike.

\section{The Qing in the early modern trade network}

The earliest attempts of integrating the Qing into a global context can be found in the field of comparative economic history, namely Bin Wong [Wong, 2018] and Andre Gunder Frank [Frank, 1998], who seek to compare the Qing economy with Western European economies. They focus on the time period of High Qing between 1680 and 1800s, when China's advanced technology dominated the growing network of long-distance trade relations. Similarly, Matthew Mosca [Mosca, 2016. P. 110], in his chapter in "The Prospect of Global History", also concentrates primarily on the early modern period of the Qing Empire (1500-1800) and emphasizes the impact of global forces on the Qing and the Qing's contribution to those forces.

Since then, the premises of Global History have found their way into Chinese national historiography. These research approaches, intended to look for entanglements and connections, have been 
implemented in order to tell a narrative of Chinese history, including the Qing, that underlines the national unity and integrity of the People's Republic. As a result, they emphasize Chinese unique position in a global and connected network of historical processes, in a way, that is opposed to the fundamental basis of Global History. The newest amongst publications that try to integrate Chinese history into Global History - "Global History with Chinese characteristics” [Perez-Garcia, 2021] - specifically addresses the role of Global History in Chinese historiography, posing the question whether global history can really be implemented within a neo-national, patriotic environment such as Chinese academia. The national narrative of "Chinese characteristics" [zhongguo tese, 中国特色] results in the accommodation of global history within a rhetoric that emphasizes China's uniqueness: Global history has emerged as popular tool of analysis within Chinese academia, especially the analysis of modern economic growth has fuelled the interest for global history within Chinese academia and made global history a popular tool of analysis for Chinese historians [Perez-Garcia, 2021. P. 11].

Departing from these attempts at integrating the Qing into a global and connected field of Studies, I want to turn to the Qing's position in the field of Empire Studies and how this relates back to the difficult accommodation of the Qing in the field of Global Studies.

Until recent years, the Qing Empire has been mostly absent from studies analyzing the $19^{\text {th }}$ century as the age of imperialism. Peter Perdue has made the most successful attempt yet to examine the formation of the Qing Empire as an example of "Manchu colonialism" and thereby to place that process in comparative context [Perdue, 1998. 256]. Similarly, Millward proposed to identify the process of Qing empire-building as "old imperialism", in juxtaposition to "new imperialism" [Millward, 1998. Pp. 8-11], practiced by European countries in the formation of overseas, economically oriented empires, and instead placed in a line with other "old" imperial, continental empires such as the Ottoman, Habsburg and Russian Empire.

\section{Old Imperialism}

In Empire Studies, the method of comparative analysis has been applied to all kinds of units of comparison, empires, regions, civilizations. One particular sub-field that I want to call "old imperialism" has since the collapse of the Soviet Union produced various publications on the Russian Empire and its place amongst more traditional, well-studied Empires such as the British and French Empire. "Old imperialism" takes part in two specific paradigm shifts, one incited by the so-called Eurasian turn, which in encompasses Russia's pivot to the East, as well as the new, by now already well established direction of the New Qing History. An attempt of comparison between two or more heterogeneous, massive empires as are usually put into this category of "old imperialism" has to navigate a complex set of questions around the concept of "Empire" and how to write imperial history.

The term used in this paper - "old imperialism" - is intended to refer to the approach of grouping continental, multi-ethnic empires such as the Russia and Qing Empire, Ottoman Empire and Habsburg Empire together in order to compare and identity parallels in their strategies of Empire-Building. Old imperialism in this context is juxtaposed to "new Imperialism", which commonly refers to the capitalist expansion of the Western European Empires of the $19^{\text {th }}$ century [Harvey, 2003].

Several relevant studies have been published about the Habsburg Monarchy, Russian Empire, the Ottoman Empire, and the British Empire. However, systematic comparisons between the modern European empires and early-modern Eurasian empires have so far been the exception [such as Sugar, 1997, and Rieber - Miller, 2004]. 
Dominic Lieven's work [Lieven, 2002] on the expansion and decline of Russia includes valuable comparisons to the Habsburg Monarchy, as well as the Ottoman Empire, and the British Empire and is therefore able to tell a more comprehensive history of the Russian Empire-Building.

When focusing on this specific sub-group of Empires, several characteristics are highlighted, similarities that supposedly these empires share with each other. The Russian, Austro-Hungarian and Ottoman Empires are assigned the attributes of "land-based" and "early-modern", which seem to serve as very basic common denominators, but also represent the most contested characteristics. More important however, are the similarities in the Empire-Building processes and systems of these empires, namely the hub and spoke concept, when it comes to addressing the center-periphery relations, as well as the crucial factor of "multi-ethnicity".

The structures of imperial rule are conceptualized by the hub and spoke concept, or center-and-periphery relations. The imperial framework is likened to a rimless wheel, with the center (hub) and the spokes symbolizing each separate, individual relation the center has to its peripheries or colonies [Motyl, 2001. P. 16]. Emblematic of the study of multi-ethnicity as well as of the new interest sparked in the ethnic plurality of empires after 1991, is for example Andreas Kappeler's the Russian Empire as a multi-ethnic empire [Kappeler, 2008].

The New Qing History scholars pursue a similar approach as the scholars I have grouped together under "old" imperialism, in that they emphasize parallel patterns of political consolidation and cultural integration across Eurasia [Glahn, 2004. Pp. xi-xvi]. The spatial framework used by the New Qing History is the concept of "Inner Asia”, a mental map encompassing Xinjiang, Tibet, Mongolia and Manchuria, therefore the territories outside of China Proper acquired by the Qing expansion in the $17^{\text {th }}$ century. The New Qing History positions itself as directly opposed to Sinocentric notions of the Qing Empire as a "Chinese dynasty”. Instead, they emphasize the Manchu identity of the Qing rulers and their imperial rule in Inner Asia, as well as the importance of the many different ethnic identities that can be found in the vast territory of the Qing Empire. The New Qing History strives to highlight that Qing ruling strategies were fundamentally different from those of Chinese empires (Ming), and were more in line with Eurasian empires [Schneider, 2020. P. 330]. Qing empire-building in Inner Asia is placed into the wider the context of Eurasian empires that pursued similar strategies as the Qing of integrating conquered regions and peoples. Post-Timurid empires [Darwin, 2008. Pp. 13-15] such as the Qing, Mughals, Ottomans and Russians employed so-called Altaic strategy of simultaneous rule [Perdue, 2005. P. 542]. By conceptualizing the Qing as a "Eurasian polity", the Qing Empire becomes comparable to Islamic "gunpowder empires" as well as Muscovite and Habsburg empires [Dunnell, 2004. P. 4]. As a result, it became possible for the Qing to take a new position in world history - even, if not global history.

The "Eurasian turn", on the other hand, represents a paradigm shift in how the history of the Russian Empire is told, with a focus on its eastern and far eastern colonies. Scholars following this turn seeks to reflect on Russia's imperial experience within a comparative framework that includes the metropole as well as the peripheries. Similar to the direction taken by the New Qing Historians, Russian empire-building is made sense through the grid of typologies of land-based versus maritime empires, which firmly places the Russian Empire alongside dynastic and multiethnic empires of Eurasia.

While historians are discovering important differences and similarities in institutions, processes and outcomes across the expanse of Eurasia, a notable drawback of this comparative empire research is the focus on static structures, leaving aside the various interactions and transfers between the empires. Comparative and entangled history of imperial imagination and practices remains underexplored and irregularities of imperial space remain overlooked. A closer look to the transfer of knowledge, people, or concepts across the empires' borders might be necessary to achieve a comprehensive comparative analysis. 


\section{Qing Studies in national Chinese historiography}

Qing research in national Chinese historiography diverges from attempts to integrate the Qing into a framework for universal comparison between Empires. Instead, the field of Qing Studies is framed by the narrative of "unification” (統一tongyi) or "great unification" (大一統dayitong), often applied together with the theory of Sinicization. This puts several Chinese Qing scholars in direct opposition to the New Qing History, while Chinese historians are regaining their authority over the field of Qing Studies. As such, the National Project for the Compilation of Qing History (国家清史纂修 工程) is intended to write a comprehensive Qing History (清史), based on a broad range of archival documents and as such departing from and surpassing the Draft History of Qing (清史稿), published in 1928.

Global history, as it is applied as a discipline in national Chinese historiography in regard to Qing history, serves a radically different purpose than in Western academia. Global History is intended to develop a new national narrative that should foster the unification of the country. The narrative of "Unification" seeks to tell the history of the Qing Empire as a shared common past of all current ethnic groups present in the PRC. Concerning for example the Northeastern nationalities, Lan Yanchao frames the history of the Butha-Eight Banner system as integral to the national history narrative, by safeguarding the Northeastern borderlands. He points out that the officers and men of Butha eight banners made great efforts in the process of guarding the border and defending the country, which laid a solid foundation for the security and stability of the border of the Qing Dynasty [Lan Yanchao, 2014. P. 121]. Instead of interpreting their ethnic diversity as a potential for destabilizing the borderland region, they are seen as a valuable asset to the national unity of China, as a whole.

When seeking to integrate the Qing into the field of Empire Studies, one has to pose the question, how non-Western history can and should be analyzed on the basis of concepts developed for Western cases and how to understand the analytical category of "Empire" in such a way that it fits a wide range of unique historical processes of Empire-Building.

In regard to the case of the Qing Empire, scholars remain split on how to conceptualize the "Qing formation”. While Ge Zhaoguang refers to the Qing as a "colonial enterprise” [Ge Zhaoguang, 2016], at the same time he insists that the meaning of Empire has to be adapted, to include the Qing case, or not be applied at all. The application of the term "empire" onto the Qing is seen as a Western imposition that not only is simplifying complexes processes of empire-building to fit a pre-existing mold, but also does not fully grasp the role of Qing as a Chinese dynasty, by firmly concentrating on the Qing as a colonial empire.

Especially reflections on the multiethnic nature of the Qing Empire have to confront the problem of how to conceptualize "Zhongguo", not just in regard to the Empire, but also in relation to the Republican era that followed. Gao Zhang points out that the Manchu Emperors expanded the definition of Zhongguo (中國) and made it "flexible" by using that term to refer to the entire empire and all of its subjects as “zhongguo zhi renmin” (中国之人民). He argues that China's modern national identity as a multiethnic unified state stems from this re-interpretation by the Qing [Zhao, 2006]. A conceptualization of Qing history as a "colonial empire" is therefore also seen as a threat to territorial unity of China in regard to territories that were conquered under the Qing [Ge Zhaoguang, 2016].

\section{New Imperial History}

"New Imperial History" offers a novel approach to the study of Empire that intends to redefine the category of Empire and as a result include empires that previously remained at the fringes of the field. 
The origin of "New Imperial History" lies in studies on the British Empire [Armitage, 2009], deployed to study the $19^{\text {th }}$ and $20^{\text {th }}$ centuries. At the same time, but quite apart from Western European histories, a body of new writing on Russian and Soviet history was developed around the journal $\mathrm{Ab}$ Imperio. Sergey Glebov and Ilya Gerasimov, to name two of the editors of Ab Imperio, pose questions regarding ethnicity and nationality, colonial relationships of domination, and altogether reflect on the potential of empire as a critical analytical category [Gerasimov, 2010. P. 7].

The paradigm shifts of the "Imperial turn" are conceived as a departure from conventional economy based theories of studying imperialism and no longer frames imperial expansion as imperialism. Instead, by framing imperial expansion as Empire-Building it puts an emphasis on the collaboration with local groups as mediators between center and periphery and as facilitators of Empire-Building. Empire-Building itself is framed as a process of negotiating and highlights the agency of local groups at the periphery. "New Imperial History" is moving away from Imperialism theories that frame imperial expansion as a result of economic problems of the center. Newer theories conceptualize Empire-Building as a hybrid process, in which both conquerors and conquered participated and in which transfer between periphery and center occurred in both directions [Hirschhausen, 2015. P. 756].

This approach strives for locality instead of universality, meaning it adapts a local perspective and uses less universal categories. By following this approach, scholars are looking for resemblances in local cases of Empire-Building. Often, researchers adopt a very broad definition of "Empire”, in order to include non-Western cases. However, in doing so, they run the risk of the category of "empire" essentially becoming meaningless.

The label "New Imperial History" is relatively new to the study of the Qing Empire. In order to apply the approach of "New Imperial History" to the Qing not only does one have to search for parallels and resemblances in Empire-Building strategies by adopting a local lens, but also has to put the focus on exchange of knowledge between Empires, not just within Empires and their subjects. The impulse for viewing empires no longer as unique cases that offer only imperfect points of comparison, but instead as connected and entangled, comes from the field of Subaltern studies. Supramanyan has made the for a "connected history of empires", which seeks to seeks to uncover links that operated across formal borders of imperial formations [Subrahmanyam, 1997. P. 739]. Such an approach draws equally on the "comparative" and "connected" methodologies of imperial and Global historians.

\section{Conclusion: Empires Studies and Global History}

In conclusion, there are signs that a cross - fertilization of methodologies and approaches between Global History and Empire Studies is undertaken in the development of the "New Imperial History". This convergence can lead to insightful results regarding the comparative analysis of Empire-Building. Global History is fundamentally the history of connectedness and holds great potential to locate Qing history within broader structures of Empire-Building and interactions between center and periphery.

The Qing are increasingly being recognized as an early modern Eurasian power, as a maritime as well as continental empire, and as a multiethnic empire, following a Non-Sinocentric approach. While the approach of "old" imperialism puts the multiethnic Qing state of Inner Asia at the forefront, to write a truly Global History of the Qing Empire-Building, I argue that the integration of approaches of the "New Imperial History" offers valuable additions, especially as writing a connected history of the Russian and Qing Empire.

The term "Empire" represents a category that holds great potential for the studying of the Qing History. While there have been made great strides in the analysis of Qing historical sources held in national archives, I argue that the history of the Qing should be written as a part of a global, connected history of Empires, which would be incomplete without the integration of the Qing. 
Ultimately, the integration of the Qing Empire into the field of Global history can be achieved by treating the process of Qing Empire-Building at its peripheries, such as Northern Manchuria, as a local phenomenon that can and should be compared to other frontiers, such as the Russian Empire in Siberia. The best approach of including the Qing in analyses of Empire-Building and imperialism should make use of the comparative method, integral to the field of Global History, and assuming a local-historic approach.

\section{References}

Armitage David, The British Atlantic World: 1500 - 1800. Basingstoke: Palgrave Macmillan, 2009.

Crossley Pamela K., A Translucent Mirror: History and Identity in Qing Imperial Ideology. The Philip E. Lilienthal Asian Studies Imprint. Berkeley: University of California Press, 1999.

Darwin John, After Tamerlane: The Rise and Fall of Global Empires, 1400-2000. London: Penguin, 2008.

Dunnell Ruth W., Elliott Mark C., Foret Philippe, and Millward James A., New Qing Imperial History: The Making of Inner Asian Empire at Qing Chengde. Richmond: Taylor and Francis, 2004.

Elliott Mark C., The Manchu Way: The Eight Banners and Ethnic Identity in Late Imperial China. Stanford, Calif.: Stanford UnivPress, 2006.

Frank Andre Gunder, ReOrient: Global Economy in the Asian Age. Berkeley: University of California Press, 1998.

Ge Zhaoguang, 葛兆光. “Between Name and Reality - the Debate on 'Sinicization', 'Colonization” and “Empire“ [名实之间一有关「汉化」、「殖民」与「帝国」的争论 ] // Journal of Fudan University [复旦学报] no.6 (2016): Pp. 1-11.

Gerasimov Ilya, Glebov Sergey, Kusber Jan, Mogilner Marina, and Semyonov Alexander. New Imperial History And The Challenges Of Empire // Empire Speaks Out. Languages of Rationalization and Self-Description in the Russian Empire. Leiden: Brill, 2010. Pp. 1-32.

Glahn Richard v. Introduction // Struve Lynn A. (ed.) The Qing Formation in World-Historical Time. Cambridge, Mass.: Harvard University Asia Center, 2004. Pp. XI-XVI.

Harvey David, The New Imperialism. Clarendon Lectures in Geography and Environmental Studies. Oxford: University Press, Incorporated, 2003.

Hirschhausen Ulrike v., “A New Imperial History? Programm, Potenzial, Perspektiven.” Geschichte und Gesellschaft 41, no. 4 (2015): Pp. 718-57.

Hostetler Laura, Qing Colonial Enterprise: Ethnography and Cartography in Early Modern China. Chicago: Univ of Chicago Press, 2001.

Kappeler Andreas, Rußland als Vielvölkerreich: Entstehung - Geschichte - Zerfall. Beck’sche Reihe 1447. München: Beck, 2008.

Lan Yanchao, 兰延超, and Li Deshan李德山. 清代布特哈八旗编设的历史作用 [Qingdai Buteha Baqi She de Lishi Zuoyong, The Historical Roles of the Establishment of the Butha Eight Banners in the Qing Dynasty] // Academic Exploration [学 术探索] no. 6 (2014): Pp. 119-125.

Lieven Dominic, Empire: The Russian Empire and Its Rivals. New Haven: Yale UnivPress, 2002.

Millward James A., Beyond the Pass: Economy, Ethnicity, and Empire in Qing Central Asia, 1759-1864. Stanford: Stanford UnivPress, 1998.

Mosca Matthew, The Qing Empire in the Fabric of Global History // Belich James, John Darwin, Margret Frenz, and Chris Wickham. The Prospect of Global History. Oxford: University Press, 2016. 108-123. 
Motyl Alexander J., Imperial Ends: The Decay, Collapse, and Revival of Empires. New York: Columbia UnivPress, 2001.

Perdue Peter C., China Marches West: The Qing Conquest of Central Eurasia. Cambridge: Belknap Press of Harvard University Press, 2005.

Perdue Peter C., Comparing Empires: Manchu Colonialism // The International History Review 20, no. 2 (1998): Pp. 255-62.

Perez-Garcia Manuel., Global History with Chinese Characteristics: Autocratic States along the Silk Road in the Decline of the Spanish and Qing Empires 1680-1796. Palgrave Studies in Comparative Global History. Singapore: Springer Singapore Imprint: Palgrave Macmillan, 2021.

Rawski Evelyn S., Presidential Address: Reenvisioning the Qing: The Significance of the Qing Period in Chinese History // The Journal of Asian Studies 55, no. 4 (1996): Pp. 829-50.

Rieber Alfred J. and Miller A.I. (ed.) Imperial Rule. Budapest: Central European University Press, 2004.

Schneider Julia C., A Non-Western Colonial Power? The Qing Empire in Postcolonial Discourse // Journal of Asian History. 54, no. 2 (2020): Pp. 311-42.

Subrahmanyam Sanjay, Connected Histories: Notes towards a Reconfiguration of Early Modern Eurasia // Modern Asian Studies 2, 31, 3, no. 3 (1997): Pp. 735-762.

Sugar Peter F., Nationality and Society in Habsburg and Ottoman Europe. Collected Studies Series 566. Aldershot: Variorum, 1997.

Wong Bin R., China Transformed: Historical Change and the Limits of European Experience. Ithaca: Cornell University Press, 2018.

Zhao Gang, Reinventing China: Imperial Qing Ideology and the Rise of Modern Chinese National Identity in the Early Twentieth Century // Modern China 32, no. 1 (2006): Pp. 3-30. 